\title{
Outcomes of Laparoscopic Transperitoneal Pyeloplasty for the Treatment of Ureteropelvic Junction Obstruction in Adult Patients
}

\author{
Üreteropelvik Bileşke Darlığı Nedeniyle Erişkin Hastalarda Uygulanan Laparoskopik \\ Transperitoneal Pyeloplasti Sonuçları
}

\author{
(1) Çetin Demirdağ, (1) Oktay Özman, (1) Sinharib Çitgez, (1) Bülent Önal, (1) Zübeyr Talat \\ Istanbul University Cerrahpaşa Faculty of Medicine, Department of Urology, İstanbul, Turkiye
}

What's known on the subject? and What does the study add?

There are limited studies related to laparoscopic pyeloplasty in adult patients. The technique may be a gold standart treatment method in this patient group. Our study shows that the technique has low complication rate.

\begin{abstract}
Objective: Laparoscopic transperitoneal pyeloplasty (LTP) is being widely preferred in the treatment of ureteropelvic junction obstruction (UPJO). This study aims to assess the outcomes of treatment efficacy of LTP performed in our clinic for the treatment of UPJO in adult patients.

Materials and Methods: Data of patients, who underwent LTP procedure in our clinic between 2004 and 2017, were reviewed retrospectively. Data of 116 patients in total were included in the study. The cases were reviewed in terms of demographic characteristics, complaints at admission, and clinical, laboratory and radiological findings. The patients were divided into two groups and correlation of demographic data (age, age group, and gender), side and presence of kidney stone with the presence of crossing vessel was investigated. Chi-square test, Student's t-test and Fisher's exact test were applied for statistical analysis.

Results: The mean age of the patients was 29.9 (19-51) years. Eight patients were the secondary patients who underwent open surgery upon diagnosis of UPJO. Forty-one (35.3\%) patients had the anomaly of crossing vessel compression, 17 (14.6\%)-kidney stone, 5 (4.3\%)-solitary kidney and $3(2.5 \%)$ had horseshoe kidney. The mean operating time was 124 (80-245) minutes. No statistically significant correlation of the presence of crossing vessel with age, gender, side and presence of stone was found. The mean length of hospital stay was 3.05 (2-11) days and the mean postoperative follow-up time was $44(12-120)$ months. Success rate was found to be $93.1 \%$. One (0.8\%) patient had perioperative and $10(8.6 \%)$ patients had postoperative complications.

Conclusion: LTP is a feasible, effective and reliable option in the treatment of UPJO with low complication rate and high success rate. Keywords: Laparoscopy, Pyeloplasty, Ureteropelvic junction, Obstruction
\end{abstract}

Öz

Amaç: Laparoskopik transperitoneal pyeloplasti (LTP), üreteropelvik bileşke darlığı (ÜPBD) tedavisinde artan bir sıklıkta tercih edilmektedir. Bu çalışmada, kliniğimizde ÜPBD tedavisinde uyguladığımız LTP yönteminin tedavi etkinliği üzerine sonuçlarını değerlendirmeyi amaçladık.

Gereç ve Yöntem: Kliniğimizde 2004 ve 2017 yılları arasında LTP uygulanan hastaların verileri retrospektif olarak incelendi. Toplam 116 hastanın verileri çalışmaya dahil edildi. Olguların demografik özellikleri, başvuru yakınmaları, klinik, laboratuvar ve radyolojik görüntü bulguları incelendi. Hastalar iki gruba ayırılarak demografik veriler (yaş, yaş grubu, cinsiyet), taraf ve böbrek taşı varlığı ile çaprazlayan damar varlığı arasındaki ilişki araştırıldı. İstatistiksel analizde ki-kare, Student's t-testi, Fisher exact testi kullanıldı.

Bulgular: Hastaların ortalama yaşı 29,9 (19-51) idi. Hastaların 8 tanesi ÜPBD tanısıyla açık cerrahi uygulanmış olan sekonder hastalardı. Hastaların 41 'inde $(\% 35,3)$ çaprazlayan damar basısı, 17 'sinde $(\% 14,6)$ böbrek taşı, 5'inde $(\% 4,3)$ soliter böbrek ve 3'ünde $(\% 2,5)$ de at nalı böbrek anomalisi saptandı. Operasyon süresi ortalama 124 (80-245) dakikaydı. Çaprazlayan damar varlığı ile yaş, cinsiyet, taraf ve taş varlığı arasında istatistiksel

Correspondence: Çetin Demirdağ MD, İstanbul University Cerrahpaşa Faculty of Medicine, Department of Urology, İstanbul, Turkiye Phone: +90 5333682319 E-mail: cetindemirdag@gmail.com ORCID-ID: orcid.org/0000-0002-8912-9155 Received: 26.02.2018 Accepted: 27.04.2018

Cite this article as: Demirdağ Ç, Ozman O, Çitgez S, Önal B, Talat Z. Outcomes of Laparoscopic Transperitoneal Pyeloplasty for the Treatment of Ureteropelvic Junction Obstruction in Adult Patients. J Urol Surg 2018;5(3):174-179.

๑Copyright 2018 by the Association of Urological Surgery / Journal of Urological Surgery published by Galenos Publishing House. 
anlamlı ilişki saptanmadı. Hastanede yatış süresi ortalama 3,05 (2-11) gün, operasyon sonrası izlem süresi ortalama 44 (12-120) aydı. Başarı oranı $\% 93,1$ olarak saptandı. Hastaların 1 'inde $(\% 0,8)$ peroperatif, 10'unda $(\% 8,6)$ ameliyat sonrası komplikasyon gözlendi.

Sonuç: LTP, düşük komplikasyon oranları, yüksek başarı oranları ile ÜPBD tanılı hastaların tedavisinde uygulanabilir, etkin ve güvenilir bir seçenektir. Anahtar Kelimeler: Laparoskopi, Pyeloplasti, Üreteropelvik bileşke, Darlık

\section{Introduction}

Ureteropelvic junction obstruction (UPJO) is the most common congenital cause of upper urinary tract obstructon resulting in progressive dilatation of the renal collecting system (1). Clinical signs of UPJO include flank pain, renal colic and infection; and may result in progressive loss of renal function (1). The gold standard for the treatment of UPJO is open pyeloplasty, described by Anderson-Hynes, with a success rate of over $90 \%$ $(2,3)$. Minimally invasive approaches in UPJO are endoscopic treatment, laparoscopic pyeloplasty and robotic pyeloplasty.

Laparoscopic pyeloplasty was first introduced in 1993 by Schuessler et al. (4) and was started to be used as a minimally invasive option at a level which can compete with open pyeloplasty in terms of success rates. Beside the improvement offered by this treatment option, the most important superiority for the patients is that the treatment is less invasive and thus results in low morbidity.

The aim of this study was to present the outcomes and associated complications in an adult patient group, who underwent laparoscopic transperitoneal pyeloplasty (LTP).

\section{Materials and Methods}

Data of 116 patients who underwent LTP in our clinic between 2004 and 2017 was retrospectively reviewed. Demographic characteristics, complaints at admission and the clinical, laboratory and radiologic findings of the patients were investigated. Indications for surgery were symptomatic UPJO such as pain, urinary tract infection, impaired renal function, and/or decline in renal function over time monitored on a diuretic renal scan. Laparoscopic approach was performed in all cases.

Perioperative complications were classified according to the Satava (5) classification and the postoperative complications according to the Clavien classification (6). The patients were followed up postoperatively on the basis of radiologic and laboratory findings. For assessment purposes, ultrasonography (US) was taken at month 1-3 postoperatively and mercaptoacetyltriglycine (MAG-3) scintigraphy at month 6 postoperatively and, the follow-up intervals were planned accordingly.

The patients were divided into two groups according to the presence of crossing vessels. Demographic data (age, age group, and gender), side, previous renal surgery and presence of kidney stone were investigated in both groups.

This was a retrospective study and all patients provided written informed consent. Ethics committee approval was not obtained because of the retrospective design of the study.

\section{Statistical Analysis}

The data was analyzed with the Statistical Package for the Social Sciences version 16 (SPSS Inc., Illinois, United States of America). Chi-square test, Student's t-test and Fisher's exact test were used in statistical analysis. A p-value of less than 0.05 was considered statistically significant.

\section{Results}

Data of 116 patients in total was included in the study (Table 1). The mean age was 29.9 (19-51) years. Seventy-six patients were male and 40 were female. Sixty-eight patients had UPJO on the left side whereas 48 patients on the right side. There were 17 (14.6\%) patients who had kidney stone and 41 (35.3\%) patients had crossing vessel. There were $3(2.5 \%)$ patients with horseshoe kidney anomaly, whereas 5 (4.3\%) patients had solitary kidney. In 8 (6.9\%) patients, there was a history of previous pyeloplasty surgery. The mean operating time was 124 (80-245) minutes. While the colon was medialized in 108 patients, the transmesocolic approach was used in 8 patients. Y-V plasty was performed in 11 patients and dismembered pyeloplasty in 105 patients. Intraoperative double-J stent was laparoscopically implanted in all patients.

The mean length of hospital stay was 3.05 (2-11) days and the mean postoperative follow-up time was 44 (12-120) months. During the perioperative period, grade 3 complication was observed in $1(0.8 \%)$ patient on the basis of the Satava classification; whereas during the postoperative period, 2 $(1.7 \%)$ patients had grade $1,7(6 \%)$ patients had grade 2 and $1(0.8 \%)$ patient had grade 3 complications on the basis of the Clavien classification (Table 2). In 1 patient, perioperative colon injury was observed during port insertion. Primary repair was performed laparoscopically in this patient. During the postoperative period, 3 patients had prolonged extravasation of urine, 5 patients had paralytic ileus and 2 had high fever. Percutaneous nephrostomy catheter was inserted in one of the patients who developed extravasation of urine. Eight (6.9\%) patients had recurrent obstruction during the follow-up. Endopyelotomy was performed in 7 (6.1\%) of these patients 
Table 1. Characteristics of patients and demographic datas

\begin{tabular}{ll}
\hline Patient characteristics & $\mathbf{n}$ \\
\hline Number of patients & 116 \\
Age (year) & \\
Mean (range) & $29.9(19-51)$ \\
Sex & \\
Female & $40(34.5 \%)$ \\
Male & $76(65.5 \%)$ \\
Side & \\
Left kidney & $68(58.6 \%)$ \\
Right kidney & $48(41.4 \%)$ \\
Primer/seconder & \\
Primer & $108(93.1 \%)$ \\
Seconder & $8(6.9 \%)$ \\
ASA score (mean) & 1.4 \\
Concomitant renal abnormality & \\
Crossing vessel & \\
Kidney stone & $41(35.3 \%)$ \\
Solitary kidney & $17(14.6 \%)$ \\
Horseshoe kidney & $5(4.3 \%)$ \\
HCT level (preoperative) & $3(2.5 \%)$ \\
Mean (range) & \\
Creatinine level (preoperative) & $39(26-45)$ \\
Mean (range) & \\
Clinical features & \\
Pain & $0.90(0.5-1.3)$ \\
No symptom & \\
Urinary system infection & \\
Hematuria & \\
\hline ASA: American Society of Anaesthesiologists, HCT: Hematocrit & \\
\hline
\end{tabular}

for recurrence. Two of these patients were tertiary cases, who underwent LTP following open pyeloplasty. Nephrectomy was performed in one patient.

No statistically significant correlation of the presence of crossing vessel with age, gender, side, previous renal surgery, and presence of stone was found (Table 3).

\section{Discussion}

Since it was first defined by Schuessler et al. (4) in 1993 as a surgical treatment of UPJO, laparoscopic management of this condition has become an ideal alternative to open and endoscopic techniques. The decision for open, laparoscopic, endoscopic or robotic managements depends on the preference and experience of the surgeon with each method having its own pros and cons. The endoscopic and laparoscopic developments in the last 2 decades and recent robotic developments in the last
Table 2. Per- and postoperative findings

\begin{tabular}{|c|c|}
\hline Per- and postoperative findings & $\mathbf{n}$ \\
\hline \multicolumn{2}{|l|}{ Operation time (min) } \\
\hline Mean (range) & $124(80-245)$ \\
\hline \multicolumn{2}{|l|}{ Approach } \\
\hline Colon reflecting & 108 (93.1\%) \\
\hline Transmesocolic & $8(6.9 \%)$ \\
\hline \multicolumn{2}{|l|}{ Technique } \\
\hline Dismembered & $105(90.5 \%)$ \\
\hline Y-V plasty & $11(9.5 \%)$ \\
\hline \multicolumn{2}{|l|}{ Bleeding $(\mathrm{mL})$} \\
\hline Mean (range) & $38(22-53)$ \\
\hline \multicolumn{2}{|l|}{ HCT level (postoperative) } \\
\hline Mean (range) & $37.8(26-43)$ \\
\hline \multicolumn{2}{|l|}{ Creatinine level (postoperative) } \\
\hline Mean (range) & $0.93(0.5-1.3)$ \\
\hline \multicolumn{2}{|c|}{$\begin{array}{l}\text { Peroperative complications according to } \\
\text { Satava classification }\end{array}$} \\
\hline Grade 3 & $1(0.8 \%)$ \\
\hline \multicolumn{2}{|c|}{$\begin{array}{l}\text { Postoperative complications according to } \\
\text { Clavien classification }\end{array}$} \\
\hline Grade 1 & $2(1.7 \%)$ \\
\hline Grade 2 & $7(6.0 \%)$ \\
\hline Grade 3 & $1(0.8 \%)$ \\
\hline \multicolumn{2}{|l|}{ Hospitalization time (days) } \\
\hline Mean (range) & $3.05(2-11)$ \\
\hline \multicolumn{2}{|l|}{ Results } \\
\hline Succeed & $108 / 116(93.1 \%)$ \\
\hline Recurrence & $8 / 116(6.9 \%)$ \\
\hline \multicolumn{2}{|l|}{ Follow-up (months) } \\
\hline Mean (range) & $44(12-120)$ \\
\hline
\end{tabular}

Table 3. The correlation between crossing vessel and demographic datas

\begin{tabular}{llll}
\hline Variables & $\begin{array}{l}\text { Crossing } \\
\text { vessel (+) }\end{array}$ & $\begin{array}{l}\text { Crossing } \\
\text { vessel (-) }\end{array}$ & p \\
\hline Age (year, mean) & $29.16 \pm 14.9$ & $30.11 \pm 14.87$ & $0.99^{*}$ \\
Male gender & $28 / 41$ & $48 / 75$ & $0.52^{* *}$ \\
Left side & $24 / 41$ & $44 / 75$ & $0.82^{* *}$ \\
Kidney stone & $3 / 41$ & $14 / 75$ & $0.23^{* * *}$ \\
\hline
\end{tabular}

*Student's t-test, ${ }^{* *}$ chi-square test, ${ }^{* * *}$ Fisher exact test

5-10 years have shifted the surgeon's preference to minimally invasive techniques. All factors including cost, available surgical equipments and experience are determinant in the surgical technique to prefer. It has been reported by many series that operative time in open pyeloplasty was significantly shorter than in laparoscopic pyeloplasty. Yet, laparoscopic pyeloplasty has 
become the method of choice as gold standard therapy in some centers due to advantages of shorter time of hospitalization and less analgesic requirement $(7,8)$. In our series, all cases were treated laparoscopically. The success rate of 93.1\% reported in our study is comparable to the results reported by experienced laparoscopic surgeons in the literature $(9,10,11)$.

The most significant symptom in adult patient group with UPJO is pain. UPJO may be found in work-ups done upon complaints of pain with micturition and blood in urine. UPJO may also be coincidentally found during tests run for other complaints without any symptom at all (12). In our series, 50\% of patients presented with pain, $18.1 \%$ with urinary tract infection and 5.2\% with hematuria. $26.7 \%$ of patients were diagnosed as asymptomatic.

Almost 30\% of the patients have crossing vessel at the UPJ (13). In our series, 41 (35.3\%) patients presented with crossing vessel, $17(14.6 \%)$ with kidney stone, 5 (4.3\%) with solitary kidney and $3(2.5 \%)$ presented with horseshoe kidney anomaly. Correlation of the presence of crossing vessel with UPJO or the effect of vascular transposition or ligation on results of pyeloplasty is debatable. Zeltser et al. (14) detected crossing vessel in almost $20 \%$ of patients with a normal UPJ. On the other hand, patients presenting with UPJO were found to have crossing vessel more commonly than the normal population (15). Almost 35.3\% of the patients in our study had crossing vessel. There was no statistically significant relationship between presence of crossing vessel and any demographic feature.

Dismembered pyeloplasty is the most frequently preferred surgical technique (16). The advantage of dismembered pyeloplasty is removal of the narrow segment, and yet it is technically more challenging than non-dismembered pyeloplasty since the ureter is divided (4). Since the ureter is not divided in non-dismembered pyeloplasty, the first suture, in particular, is put without tension with a shorter anastomosis time. There is an obvious need for more scientific data to conclude whichever method is better for patients. In our series, 82\% of the patients underwent dismembered pyeloplasty.

Although the Anderson-Hynes dismembered pyeloplasty is the most common technique, there are many different techniques applicable according to the pelvic anatomy. Foley Y-V plasty is the most commonly used non-dismembered technique. This technique designed for high ureteral access cannot be applied when the lower pole vessel needs to be transposed. However, crossing vessel has not always been shown to be responsible for UPJO (17). Furthermore, the success rate of Y-V plasty applied in the presence of crossing vessel is comparable to Anderson-Hynes plasty (10). In our series, 1 out of 10 patients undergoing Foley Y-V plasty presented with crossing vessel. It was decided in these cases that the crossing vessels could not be responsible for the external compression since they were localized to the proximal of the UPJ. Besides, the UPJ extends more to the proximal in Y-V plasty moving away from the crossing vessel.

The study presenting our 14-year laparoscopic pyeloplasty experience confirms that $\mathrm{Y}-\mathrm{V}$ plasty was rather preferred in the first years, later on replaced totally by dismembered pyeloplasty. Other authors sharing their first 100-case experiences have shown to prefer the $Y-V$ technique in the same ratios $(9,10,11)$. Nevertheless, these studies did not report until when and how much this technique was applied down the learning curve.

Presence of stone does not hinder the laparoscopic technique in the presence of UPJO. Ramakumar et al. (18) published a 20case series having undergone simultaneous pyelotomy in 2002. Similarly, preoperative assessment of 17 (14.6\%) cases revealed stone in our study, following which laparoscopy-guided simultaneous pyelolithotomy was applied.

Although horseshoe kidney may look as a challenge for laparoscopic approach, it has been reported in a few studies $(19,20)$. In our series, $3(2.5 \%)$ patients with horseshoe kidney anomalies underwent LTP. Consequently, laparoscopic pyeloplasty has been successfully applied in patients with renal anomalies.

Laparoscopic pyeloplasty can successfully be applied in recurrent patients who had previous surgery for UPJO. However, it is not at all times easy to create a favorable space and make ureter dissection due to the adherences resulting from a previous surgery. The operator is expected to have advanced laparoscopic experience to make a tension-free anastomosis (21). In our series, $8(6.9 \%)$ patients had a history of open pyeloplasty. Six (5.2\%) of these patients did not develop recurrence during follow-up, whereas $2(1.7 \%)$ patients had recurrent obstruction. One $(0.8 \%)$ patient had endopyelotomy. The other $(0.8 \%)$ patient had failed and thus later required nephrectomy.

The transmesocolic approach was used in 8 (6.9\%) patients of our series. In particular, in left-sided UPJOs, incision and dissection through the Toldt line for colon mobilization in transperitoneal approach restrict laparoscopic vision due to bleeding and fog and extend the operating time. For this reason, transmesocolic approach is preferred by certain centers for left-sided UPJO. There are reports of shorter operating times in the literature when compared to the transperitoneal method in other series $(22,23)$. Although the transmesocolic technique lasts shorter as the colon is not taken down, this technique is not widely preferred since it is eligible for younger and lean patients with low mesenteric adipose tissue (24). This technique was preferred in only $8(6.9 \%)$ patients in our series. No comparison was made since we had a low number of patients with the transmesocolic approach.

There are series of pyeloplasty performed without use of double-J stent in the literature $(25,26)$. There are studies suggesting that 
stentless pyeloplasty is a safe and feasible technique. In 2007, Shalhav et al. (27) published the outcomes of 5 of their patients in whom they performed laparoscopic stentless pyeloplasty. Dismembered technique was preferred for all patients. Double-J stent was used in all patients who underwent LTP in our study. Double-J stent was removed on postoperative month 1 in average.

During the perioperative period $1(0.8 \%)$ patient had grade 3 complication on the basis of the Satava classification; and during the postoperative period, $2(1.7 \%)$ patients had grade 1, $7(6 \%)$ patients had grade 2 and $1(0.8 \%)$ patient had grade 3 complication on the basis of the Clavien classification (Table 2). One patient $(0.8 \%)$ had perioperative left colon injury during port insertion. Primary repair was performed laparoscopically in this patient. This patient did not have any associated problem postoperatively. The postoperative complication rate was found to be $8.6 \%$. Two $(1.7 \%)$ patients had high fever (grade 1), 3 (2.6\%) patients had prolonged extravasation of urine (grade 2) and $5(4.3 \%)$ patients had paralytic ileus (grade 2). These patients improved during postoperative follow-up with medical treatment. Percutaneous nephrostomy catheter was inserted in one $(0.8 \%)$ of the patients with extravasation of urine (grade 3 complication).

The mean follow-up time was $44(12-120)$ months. There is no common consensus about the follow-up duration. In our clinic, US was taken at month 1-3 postoperatively and MAG-3 scintigraphy at month 6 postoperatively for assessment purposes and the follow-up intervals were planned accordingly. During the followup, 8 (6.9\%) patients had recurrent obstruction. Endopyelotomy was applied in 7 (6.1\%) patients for recurrence. Two (1.7\%) of these patients were tertiary cases, who underwent LTP following open pyeloplasty. One (0.8\%) patient had nephrectomy. Complications are similar when compared to the literature $(9,10,11)$.

\section{Study Limitations}

Outcomes and complication rates in adult patients who underwent LTP in our center are presented in this study. This study suggests that LTP is technically feasible in adult patients with UPJO. However, our study has several limitations. The data were collected longitudinally and verified retrospectively, which could have introduced error. Another limitation of our study is that we did not compare the technique with open surgery. However, we performed the general principles of open surgery during the procedure. Despite these limitations, our results suggest that LTP is a safe and feasible treatment in the management of UPJO. Future studies should be prospectively designed to overcome the existing limitations.

\section{Conclusion}

LTP is an effective and safe approach in surgical treatment of adult patients diagnosed with UPJO. It may be a first-line therapy with its low complication rates, eligibility in patients with anatomic variations and short hospital stay.

\section{Ethics}

Ethics Committee Approval: Ethics committee approval was not applied because of retrospective design of the study.

Informed Consent: All patients provided a signed informed consent form.

Peer-review: Externally peer-reviewed.

\section{Authorship Contributions}

Surgical and Medical Practices: Ç.D., B.Ö., Concept: Ç.D., O.Ö., Design: Ç.D., S.Ç., Data Collection or Processing: Ç.D., B.Ö., S.Ç., Analysis or Interpretation: S.Ç., O.Ö., Z.T., Literature Search: 0.0̈., Writing: Ç.D., B.Ö., O.Ö.

Conflict of Interest: No conflict of interest was declared by the authors.

Financial Disclosure: The authors declared that this study received no financial support.

\section{References}

1. Stasinou $T$, Bourdoumis A, Masood J. Forming a stone in pelviureteric junction obstruction: Cause or effect? Int Braz J Urol 2017;43:13-19.

2. Koff SA, Hayden $\amalg$, Cirulli C, Shore R. Pathophysiology of ureteropelvic junction obstruction: experimental and clinical observations. J Urol 1986;136:336-338.

3. Bernstein GT, Mandell J, Lebowitz RL, Bauer SB, Colodny AH, Retik AB Ureteropelvic Junction Obstruction in the Neonate. J Urol 1988;140:12161221.

4. Schuessler WW, Grune MT, Tecuanhuey LV, Preminger GM. Laparoskopic dismembered pyeloplasty J Urol 1993;150:1795-1799.

5. Satava RM. Identification and reduction of surgical error using simulation Minim Invasive Ther Allied Technol 2005;14:257-261.

6. Dindo D, Demartines N, Clavien PA. Classification of surgical complications: a new proposal with evaluation in a cohort of 6336 patients and results of a survey. Ann Surg 2004;240:205-213.

7. Symons SJ, Bhirud PS, Jain V, Shetty AS, Desai MR. Laparoscopic pyeloplasty: our new gold Standard. J Endourol 2009;23:463-467.

8. Moon DA, El-Shazly MA, Chang CM, Gianduzzo TR, Eden CG. Laparoscopic pyeloplasty: evolution of a new gold standard. Urology 2006;67:932-936.

9. Jarrett TW, Chan DY, Charambura TC, Fugita O, Kavoussi LR. Laparoscopic pyeloplasty: The first 100 cases. J Urol 2002;167:1253-1256.

10. Szydelko T, Kasprzak J, Lewandowski J, Apoznanski W, Dembowski J. Dismembered laparoscopic Anderson-Hynes pyeloplasty versus nondismembered laparoscopic Y-V pyeloplasty in the treatment of patients with primary ureteropelvic junction obstruction: a prospective study. J Endourol 2012;26:1165-1170.

11. Singh 0, Gupta SS, Arvind NK. Laparoscopic pyeloplasty: an analysis of first 100 cases and important lessons learned. Int Urol Nephrol 2011;43:85-90.

12. Park JM, Bloom DA. The pathophysiology of UPJ obstruction. Current concepts. Urol Clin North Am 1998;25:161-169. 
13. Van Cangh PJ, Nesa S, Galeon M, Tombal B, Wese FX, Dardenne AN, Opsomer $R$, Lorge $F$. Vessels around the ureteropelvic junction: significance and imaging by conventional radiology. J Endourol 1996;10:111-119.

14. Zeltser IS, Liu JB, Bagley DH. The incidence of crossing vessels in patients with normal ureteropelvic junction examined with endoluminal ultrasound. J Urol 2004;172:2304-2307.

15. Sampaio FJ. Vascular anatomy at the ureteropelvic junction. Urol Clin North Am 1998;25:251-258.

16. Gallo $F$, Schenone M, Giberti C. Ureteropelvic junction obstruction: which is the best treatment today? J Laparoendosc Adv Surg Tech A 2009;19:657662 .

17. Lawler LP, Jarret TW, Corl FM, Fishman EK. Adult Ureteropelvic Junction Obstruction: Insights with Three-dimensional Multi-Detector Row CT. Radiographics 2005;25:121-134.

18. Ramakumar S, Lancini V, Chan DY, Parsons JK, Kavoussi LR, Jarrett TW. Laparoscopic pyeloplasty with concomitant pyelolithotomy. J Urol 2002;167:1378-1380.

19. Hsu TH, Presti JC Jr. Anterior extraperitoneal approach to laparoscopic pyeloplasty in horseshoe kidney: a novel technique. Urology 2003;62:11141116.

20. Janetschek G, Peschel R, Altarac S, Bartsch G. Laparoscopic and retroperitoneoscopic repair of ureteropelvic junction obstruction. Urology 1996;47:311-316.
21. Parma P, Samuelli A, Luciano M, Dall'Oglio B. [Salvage laparoscopic pyeloplasty in the worst case scenario: after failed open repair and endoscopic salvage]. Urologia 2014;81(Suppl 23):9-14.

22. Porpiglia F, Billia M, Volpe A, Morra I, Scarpa RM. Transperitoneal left laparoscopic pyeloplasty with transmesocolic access to the pelvi-ureteric junction: technique description and results with a minimum follow-up of 1 year. BJU Int 2008;101:1024-1028.

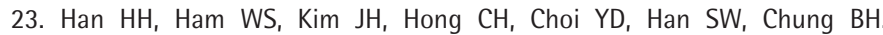
Transmesocolic Approach for Left Side Laparoscopic Pyeloplasty: Comparison with Laterocolic Approach in the Initial Learning Period. Yonsei Med J 2013;54:197-203.

24. Shadpour P, Nayyeri RK, Daneshvar R, Salimi H, Radfar H. Prospective clinical trial to compare standard colon-reflecting with transmesocolic laparoscopic pyeloplasty. BJU Int 2012;110:1814-1818.

25. Khawaja AR, Dar TI, Bashir F, Sharma A, Tyagi V, Bazaz MS. Stentless laparoscopic pyeloplasty: A single center experience. Urol Ann 2014;6:202207.

26. Smith KE, Holmes N, Lieb JI, Mandell J, Baskin LS, Kogan BA, Walker RD. Stented versus nonstented pediatric pyeloplasty: a modern series and review of the literature. J Urol 2002;168:1127-1130.

27. Shalhav AL, Mikhail AA, Orvieto MA, Gofrit ON, Gerber GS, Zorn KC. Adult stentless laparoscopic pyeloplasty. JSLS 2007;11:8-13. 